\title{
A Study of Linguistic Insecurity among Turkish Teachers of English
}

\author{
Giti Ehtesham Daftari \\ Institute of Educational Sciences, Gazi University, Ankara, Turkey \\ Tel: 90-537-054-6485Ｅ-mail: giti.ehtesham@gmail.com
}

Received: June 13, 2016 Accepted: August 6, 2016 Published: August 12, 2016

doi:10.5296/ijele.v4i2.9874 URL: http://dx.doi.org/10.5296/ijele.v4i2.9874

\begin{abstract}
This study was designed in order to investigate some aspects of the linguistic insecurity of Turkish EFL teachers and its possible sources. In the light of these aims, the study was conducted with 152 Turkish teachers at different language institutes during fall semester of 2015-2016 academic year. The study was conducted in a twelve week period and the data were collected through a questionnaire. Although the results revealed that Turkish EFL teachers experienced a low level of linguistic insecurity in their classrooms, it was found that teaching pronunciation, low level of target language proficiency and low level of knowledge on culture of target language are linguistic insecurity provoking factors.
\end{abstract}

Keywords: linguistic insecurity, Turkish EFL teachers, questionnaire, linguistic insecurity provoking factors 


\section{Introduction}

The growing importance of English language and thereupon, the increasing number of English language learners necessitate the presence of prepared and educated EFL teachers. It is an undeniable fact that the number of non-native English-speaking teachers is steadily increasing all over the world and the number of non-native English-speaking teachers overwhelms native English-speaking teachers. "In the field of English language teaching (ELT), a growing number of teachers are not native speakers of English" (Maum, 2002, p.1).

On the other hand, non-native speakers of a language are frequently confronted with negative feelings which stem from socio-cultural, racial and socioeconomic differences between them and the native speakers of that language. These feelings can affect the non-native speakers' self-perception and cause linguistic insecurity. In case of language teachers, lack of self-confidence and linguistic insecurity can disturb the learning process to a high degree.

Teachers must constantly look at how their personal beliefs and possible biases affect their ability to create the most effective environment for their students to learn and comprehend content. In the other words, teachers' gender, culture, religion, mother tongue and many other factors can influence the final outcome of their teaching (Fraser, 2014).

As the study of linguistic insecurity in case of non-native English teachers has started very recently, review of the literature reveals that no research studies have been conducted with the aim of investigating Turkish EFL teachers' linguistic insecurity. The aim of this study is to examine some issues related to the linguistic insecurity among Turkish teachers of English and its possible sources. The present study will be guided by the following research question:

1. Which factors can affect linguistic insecurity of Turkish teachers of English?

\section{Literature Review}

The anxiety or lack of confidence experienced by speakers and writers, who believe that their use of language does not conform to the principles and practices of standard language, is called linguistic insecurity. Bucci and Baxter (1984) define linguistic insecurity as the negative self-image of a speaker regarding his or her own speech variety or language. It might happen if the speaker compares his or her phonetic and syntactic characteristics of speech with those characteristics of what is perceived to be the "correct" form of the spoken language.

Moreau (1994) defines linguistic insecurity in the frame of dominant and dominated languages in a particular society. She believes it is through the relations of subgroups to the dominant group that language becomes richer and more complex as people within the minority subgroups oppose themselves to the dominant culture.

The study of linguistic insecurity is relatively recent since its emergence in 1960. The psychology specialists were the first to study the concept of linguistic consciousness among the French-English bilinguists in Canada in the 1960s. Canadian psychologists and linguists 
focused on psychological features more than linguistic aspects. It is important to note that these studies attest to the linguistic insecurity even though they do not use the term. Labov set the stage for other scholars to go further and study several aspects of linguistic insecurity in psychological, sociolinguistic and educational fields.

Linguistic insecurity is linked to the perception of speech styles in any community, and according to Labov (1966) it may vary based on socioeconomic class and gender. It is also especially pertinent in multilingual societies.

Although the term "linguistic insecurity" may be felt as somewhat inadequate in order to refer to a process of evaluation of linguistic prestige, it would be justified by the consequences it has among speakers. Thus, hypercorrection, doubt, nervousness, self-correction, erroneous perception of one's own speech pattern, or an important fluctuation between different speech styles have been associated with the language usage of insecure individuals (Labov, 2006).

Owens and Baker (1984) used the CILI (Canadian Index of Linguistic Insecurity) and ILI (Index of Linguistic Insecurity) test to conclude that women are more linguistically insecure than men. Out of a sampling data of 80 participants, 42 of which were female, women scored higher on the ILI and the CILI, a result which indicates high manifest linguistic insecurity. These findings are consistent with Labov's original New York study and lead to the conclusion by Owens and Baker that women display more linguistic insecurity than men.

While the linguistic insecurity of speakers of a language is mostly related to their pronunciation, in the case of non-native teachers it is referred to the feeling of insecurity when teaching grammar, vocabulary and also pronunciation. Individuals may have preferences about teaching particular skills or components but obviously they seem to feel unsafe when teaching special skills or components if they feel linguistically insecure about that part.

The emphasis on native speaking teachers' correctness, whatever its source, seems to have the effect of arousing feelings of linguistic insecurity among non-native speaking teachers. For non-native teachers of English, it means their acceptance of the negative stereotyping of their English by the native speaking community, regardless of the fact the kind of English spoken between its native speakers, is not appropriate to most non-native speaking communities (Jenkins, 2004).

According to Gagliardi and Maley (2010), almost 98\% of Italian foreign language teachers are native Italian speakers who often describe their linguistic insecurity in the foreign language they teach as the major professional weakness affecting the development of their professional identity. As non-natives, they experience the uneasiness of teaching a language whose cultures they have seldom been extensively exposed to. It is not only the case with Italian foreign language teachers, but also with teachers in other countries. Most of foreign language teachers in each country seem to be native speakers of that country and the feeling of linguistic insecurity is common to all non-native teachers of foreign languages.

Medgyes (1992) points out that NNESTs usually feel unsafe using the language they have to 
teach. Due to this fear, they tend to adopt two kinds of attitudes: pessimistic or aggressive. Both of these feelings are deterrent and can disturb teaching process. To recognize and investigate the main sources of feeling high level of linguistic insecurity was the initial motivation of the researcher to conduct this research study.

Linguistic insecurity of teachers with different nationalities may be affected by different factors. A review of the literature reveals that no research studies have been conducted dealing with the sources of linguistic insecurity in the case of Turkish EFL teachers. The present research study deals with some aspects that are expected to be influencing Turkish teachers' feeling of linguistic insecurity in EFL classrooms. This is a part of a large project dealing with EFL teachers' linguistic insecurity and its impact on learners' productive skills.

\section{Methodology}

\subsection{Participants}

The participants of the study included 152 Turkish EFL teachers, 102 female and 50 male, from different language institutes in Ankara, Turkey. Their ages ranges between 22 and 51 . Although they are English teachers, some of them do not have ELT background and they have studied different subjects at university. Participants' demographic information is shown in table 1 .

Table 1. Participants' Demography

\begin{tabular}{cccc}
\hline Gender & Age & Frequency & Percent \\
\hline Male & $23-51$ & 50 & 32.89 \\
Female & $22-34$ & 102 & 67.10 \\
\hline
\end{tabular}

The participants were asked to provide the length of their teaching in the field of ELT. There were 18 participants who failed to provide the information. As shown in figure 1, each response was converted to the number of months for the initial data entry.

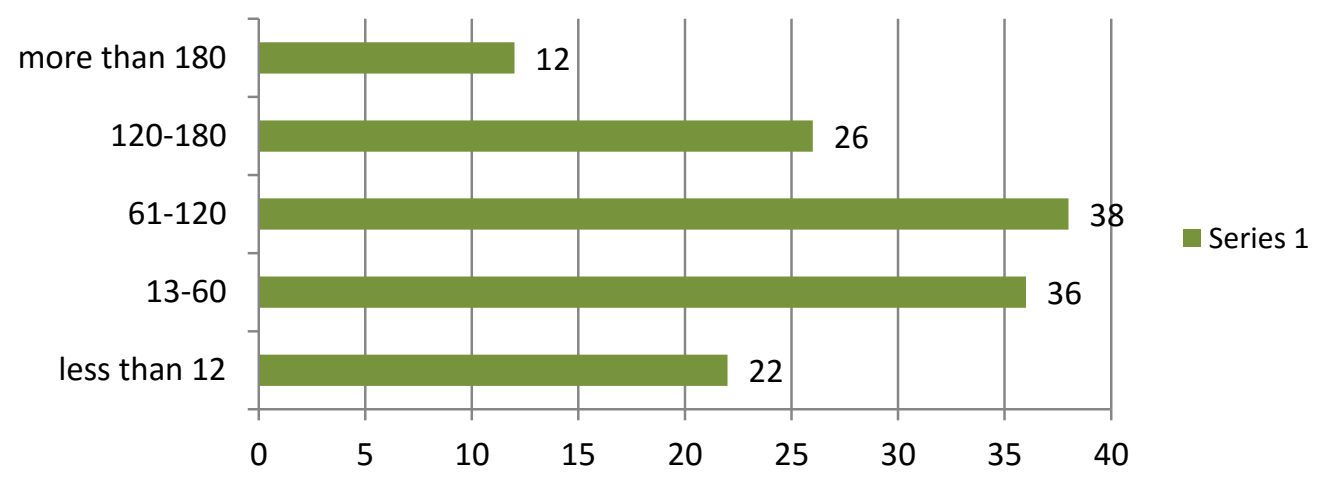

Figure 1. Study Participants by Teaching Years 


\section{Ml Macrothink}

38 out of 134 participants have been teaching English for 5 to 10 years; 36 teachers have been teaching English for 1 to 5 years; 26 teachers have an experience of English teaching for 10 to 15 years; only 12 teachers have taught English for more than 15 years and finally, 22 participants has an experience of English teaching for less than a year.

\subsection{Data Collection and Analysis}

The survey included 34 items, with options to rate each item on a scale from 1 (not at all) to 5 (a great deal) in order to examine the participants' linguistic insecurity from different respects. The quantitative data were compiled and analyzed. Means and standard deviations were calculated for each item separately and they were compared for each catalogue.

In order to ensure that the questionnaire items accurately measured what they were intended to measure, and that the format of the questions and the interaction between them would not skew the results, an expert in the field who was not involved in the study was asked to review the survey, and revisions were made to the items based on the observations made. Furthermore, testing of the internal consistency of the scale revealed a reliability coefficient of 0.75 , which indicates that the scale can be considered as a reliable data collection tool for the purposes of this study. An overview of survey items is demonstrated in table 2 .

Table 2. An Overview of Survey Items

\section{Survey Items}

\begin{tabular}{ll}
\hline Items & - I feel comfortable interacting with my native English speaking colleagues. \\
on language & - I appreciate the opportunities to improve my linguistic competence. \\
insecurity & - I have enough training to deal with almost any learning problem. \\
& - I can use classroom English without great difficulty. \\
- I can craft good questions for eliciting responses from my learners in English \\
- class. \\
- I can teach English using English only. \\
- I can provide an alternative explanation or example in English class when my \\
- learners are confused. \\
\\
- I am able to effectively teach oral language skills (listening and speaking) to \\
\\
- I my learners. \\
- I feel difficulties teaching pronunciation. \\
\end{tabular}


Items on

Self-efficacy

Perception
- I am usually able to get through to most difficult learners.

- I can adjust the difficulty level of different assignments to any learner's level.

- I believe that I know different techniques to motivate and encourage the learners who show low interest in learning English.

- My experience/ teacher training program has given me the necessary skills to be an effective EFL teacher.

- I feel necessity to attend teacher training courses.

- I am able to use a variety of assessment strategies in my English class.

- I feel comfortable when I am observed.

\begin{tabular}{|c|c|}
\hline $\begin{array}{l}\text { Items } \\
\text { On Turkish } \\
\text { Identity }\end{array}$ & $\begin{array}{l}\text { - I am very proud to be Turkish. } \\
\text { - Speaking English with my native accent is very important to me. It reflects } \\
\text { who I am and where I come from. } \\
\text { - I prefer to choose an English nickname and to pretend that I am a native } \\
\text { English teacher. } \\
\text { - I try my best to sound native to my learners. } \\
\text { - American English is the best model for Turkish learners of English. } \\
\text { - It is okay not to speak like an American because English is an international } \\
\text { language. }\end{array}$ \\
\hline $\begin{array}{l}\text { Items On } \\
\text { Cultural } \\
\text { Issues }\end{array}$ & $\begin{array}{l}\text { - Teaching the culture of target language is very important. } \\
\text { - I can help the learners understand foreign countries cultures related to their } \\
\text { English learning. } \\
\text { - I constantly follow American series and movies. } \\
\text { - I watch British TV channels. } \\
\text { - I am able to answer the learners' questions about American customs, holidays } \\
\text { and festivals. } \\
\text { - I can provide the learners with brief information about top universities of the } \\
\text { - UK and the USA. } \\
\text { - I we watch videos about foreign cultures in my classes. } \\
\text { - I put pictures about foreign cultures on the classroom walls. }\end{array}$ \\
\hline
\end{tabular}

Moreover, an author-developed demographic questionnaire was used to collect participants' age, years of English language teaching, gender, and ELT background.

Blank data: 5 participants left questions blank, and so they had to be omitted from the study.

\section{Results and Discussion}

This section will describe the results of the survey on four different issues related to linguistic 
insecurity. The purpose of this questionnaire was to gain insight into possible sources of linguistic insecurity in case of Turkish teachers of English. To this end, the mean responses given for each item were calculated and compared.

\subsection{Items on linguistic insecurity}

Table 3 shows the mean and standard deviation of participants' answers to items 1 to 11 which are about linguistic insecurity of Turkish EFL teachers. The mean for the first item, which is about interacting with native English speakers, shows the participants' high level of self-confidence on their oral linguistic competence. Items \#2 and \#3 deal with training courses and ELT background, and the overall mean ratings for these items indicate that participants strongly feel comfortable about their ELT background. Although 31 participants are not from the field of English language teaching, they do not feel necessity to attend more teacher training courses. Items \#4, \#5, \#6 and \#7 reference the participants' perception of their English proficiency and classroom English. It is seen that they feel quite confident about their classroom management, knowledge of English teaching strategies and their own capabilities.

Sali (2014) conducted a research study to investigate Turkish teachers' use of L1 in EFL classrooms and she found that they use L1 in different situations such as communicating the content of the lesson, regulating classroom interactions, and talking about cultural or social issues.

A low level of target language proficiency can be a source of linguistic insecurity among English teachers and we can conclude that the participants feel low level of linguistic insecurity according to their answers to the relevant items.

Items \#8 and \#9 reflect participants' confidence in their ability to teach different skills and the means show that they feel relatively confident in this case. It is obvious that most of the participants feel difficulty in teaching pronunciation rather than other components and skills. The last item in the first catalogue is about reviewing the lesson plan before the class and clearly, the participants prefer to have a look on the material beforehand regardless of their age. The low rate of the mean of item \#10 shows the participants lack of confidence in teaching pronunciation. It is not surprising that non-native English speaking teachers feel insecure when teaching pronunciation. Öztürk and Gürbüz (2014) also found out that teaching speaking and pronunciation are the most anxiety provoking factors in EFL classrooms.

Item \#11 shows the participants' fear of immediate questions as they feel the necessity to review the lesson plan before teaching. Table 3 shows the details of the items about linguistic insecurity.

Table 3. Linguistic Insecurity Items of the Questionnaire

\begin{tabular}{lll}
\hline Linguistic insecurity items & Mean & SD \\
\hline Item \#1 & 4.78 & 1.43 \\
Item \#2 & 4.27 & 1.55 \\
Item \#3 & 3.72 & 1.84 \\
\hline
\end{tabular}




\begin{tabular}{lll}
\hline Item \#4 & 4.55 & 1.71 \\
\hline Item \#5 & 3.97 & 1.66 \\
\hline Item \#6 & 3.72 & 1.62 \\
\hline Item \#7 & 4.59 & 1.29 \\
\hline Item \#8 & 4.65 & 1.41 \\
Item \#9 & 4.35 & 1.69 \\
Item \#10 & 3.09 & 1.78 \\
\hline Item \#11 & 4.58 & 1.32 \\
\hline
\end{tabular}

\subsection{Items on self-efficacy}

Self-efficacy can be defined as the "beliefs in one's capabilities to organize and execute the courses of action required to produce given attainments" (Bandura, 1997, p.3). The notion is based on Bandura's $(1986,1997)$ social cognitive theory which is a theory of human functioning that contributes to the idea that people can control their behavior. People may have a system of self-beliefs that allows them to workout control over their thoughts, feelings, and actions. According to this theory of human behavior, "what people think, believe, and feel affects how they behave" (Bandura, 1986, p.25).

Teacher self-efficacy, in a similar understanding, is about a teacher's "capabilities to bring about desired outcomes of student engagement and learning, even among those students who may be difficult or unmotivated" (Tschannen-Moran \& Hoy, 2001, p.784). Self-efficacy is shown as an indicator of successful teaching and it increases within years of experience and aging (Ghanizadeh \& Moafian, 2011).

Table 4 shows the mean and standard deviation of participants' answers to items related to teacher self-efficacy. The overall means reveal that Turkish EFL teachers experience a relatively high level of self-efficacy. The lowest mean belongs to item \#7 which is about being observed $(\mathrm{M}=2.98)$. No matter how long you've been teaching and no matter what your level of confidence in yourself is, you're nervous, the kids are nervous, and breathe a huge sigh of relief when the supervisor leaves. No matter what the purpose of the observation is, to work with the teacher to improve their practice and effectiveness or to evaluate teacher's performance, it seems to be irritating and nerve-breaking.

Table 4. Self-efficacy Items of the Questionnaire

\begin{tabular}{lll}
\hline Self-efficacy items & Mean & SD \\
\hline Item \#1 & 3.80 & 1.54 \\
\hline Item \#2 & 4.31 & 1.58 \\
\hline Item \#3 & 3.84 & 1.49 \\
\hline Item \#4 & 3.69 & 1.87 \\
Item \#5 & 3.75 & 1.65 \\
\hline Item \#6 & 3.51 & 1.46 \\
Item \#7 & 2.98 & 1.69 \\
\hline
\end{tabular}




\subsection{Items on participants' Turkish identity}

Demirezen (2007) explains different types of language identities: personal identity, ethnic identity, national identity, cultural identity, bilingual identity, and collective identity. A person's self-image has two components: personal and social identity. Personal identity is shaped by one's native dialect and national education process. Ethnic identity is the sense of belonging to a group. When an individual uses a dialect of a language, he indeed shares the collective consciousness of common features with a group of users from particular social group. The sense of national identity is attached to the use of a standard national language which functions as a common ground for national unity. Cultural identity is a collective identity case consisting of a couple identity types, as members of a group, a nation or a community acquiring its cultural specific vocabulary, race, context sensitive topics, shared belief(s), attitudes, superstitions, customs, structural forms of related language, alongside with idioms and proverbs, as well as the features of paralanguage and mannerisms of the entire community. Learning a second language accompanies obtaining a second identity. Professional identity refers to teachers' subject matter knowledge of their field and molding a professional identity is a developmental process of socialization, vocational behavior, and maturation. Collective identity is a combination of certain identities which speakers of a language decide to integrate.

Furthermore, he discusses the identity crisis of non-native English teachers and he concludes that non-native speaking teachers should not retain a foreign accent in their foreign language teaching profession as a foreign language right as he believes that they will not be understood by the students and it be harming learning process.

Medgyes (1992) reports that non-native teachers feel unconfident and insecure using the language they have to teach and they might suffer from Foreign Accent Syndrome (FAS), referring to a fear of speaking in the field of education. Accordingly, they tend to adopt two kinds of attitudes: pessimistic or aggressive. In Turkey, the pessimistic type is the most common one. Teachers of this type are so absorbed in grammar and vocabulary that they pay little or no attention to pronunciation (Karakaş, 2012).

However, the participants of the present study stated that they are satisfied with their Turkish accent and most of them believe that it is not very crucial to sound like native speakers of English in the classroom and they did not feel embarrassed to speak with a Turkish accent (item \#4: I try my best to sound native to my learners). The highest mean belongs to item \#1 which shows participants honor and pride about their nationality. Table 5 shows the mean and standard deviation of the seven items related to participants' perception of their Turkish identity.

Table 5. Turkish Identity Items of the Questionnaire

\begin{tabular}{lll}
\hline Turkish Identity items & Mean & SD \\
\hline Item \#1 & 4.89 & 1.21 \\
\hline Item \#2 & 3.28 & 1.83 \\
Item \#3 & 3.38 & 1.45 \\
\hline
\end{tabular}




\begin{tabular}{lll}
\hline Item \#4 & 2.85 & 1.86 \\
Item \#5 & 3.06 & 1.89 \\
\hline Item \#6 & 4.03 & 1.77 \\
Item \#7 & 4.53 & 1.32 \\
\hline
\end{tabular}

In terms of identity, the participants generally show low feeling of insecurity or disturbance during their teaching process. Very few of the Turkish EFL teachers participating in this research study believe that American English is the best model for Turkish students, the others prefer British English which many Turkish learners and their families are interested in.

\subsection{Cultural items}

According to Merç (2015), Non-native English teachers as student teachers should be aware of language learning process as well as teaching process. It means that they should enrich their knowledge of the target language in terms of culture, history, geography, sociology, and many other aspects because learning how to teach is a continuing process. The more the non-native language teachers improve their knowledge of the target culture beside the proficiency of the target language, the less they are supposed to feel linguistically insecure and uncomfortable.

Garrido and Alvarez (2006) state that language learners should be encouraged to become competent intercultural speakers because languages are related to the cultures, communities and societies that use them for communication. For this purpose, language teachers are expected to guide students in the acquisition of various skills, contributing to the development of their knowledge and understanding of a target language and culture(s), and helping them reflect on their own culture as well. Thus, language teachers have to be familiar with target culture and they should be able to help their students acquire intercultural understanding.

However, Atay et al. (2009) obtained an interesting finding in their research study conducted with 503 Turkish EFL teachers. They studied EFL teachers' attitude toward students' cultural education and found that Turkish EFL teachers expressed that they strongly support the idea that students should understand their own language better before they study the target language. They believe that this finding might be attributed to the fact that the teachers were not familiar enough with target language cultures, did not have much contact with English speaking people, and did not feel fully knowledgeable about the target culture, so that they felt more comfortable focusing on the students' and their own native culture.

Inceçay and Akyel (2014) reported that half of the participants in their research study preferred teaching English through Turkish culture. Regarding their perception about the integration of culture in language teaching, they stated that the topics taught in the language classroom should be chosen from the cultural aspects of students' native language which is Turkish. 


\section{Ml Macrothink}

In the present study, the means show that although the participants perceive the importance of the culture of target language which is English, they do not attempt to keep their cultural or social knowledge updated. Furthermore, answers to items \#7, \#8, and \#9 reveal that participants do not provide their students with cultural materials such as posters and videos. The mean of item \#5 is the highest in cultural items category. Participants are confident about their knowledge of American events and holidays which are frequently repeated in teaching books and are not considered as supplementary material. The means and standard deviations for items on cultural issues are demonstrated in table 6.

Table 6. Cultural Items of the Questionnaire

\begin{tabular}{lll}
\hline Cultural items & Mean & SD \\
\hline Item \#1 & 3.98 & 1.25 \\
\hline Item \#2 & 3.11 & 1.22 \\
\hline Item \#3 & 3.60 & 1.76 \\
\hline Item \#4 & 3.81 & 1.48 \\
\hline Item \#5 & 4.65 & 1.02 \\
\hline Item \#6 & 2.77 & 1.73 \\
\hline Item \#7 & 2.98 & 1.56 \\
\hline Item \#8 & 3.01 & 1.84 \\
\hline Item \#9 & 2.23 & 1.17 \\
\hline
\end{tabular}

\section{Conclusion}

This study aims to contribute to a more comprehensive understanding of linguistic insecurity of Turkish teachers of English by exploring its relations to cultural issues, participants' Turkish identity, and their feeling of self-efficacy. The data were collected through a questionnaire and the participants were 152 Turkish EFL teachers. The results revealed that the participants of this study generally experienced a low level of linguistic insecurity in their classrooms.

Some important implications can be derived from the results. First, the study showed that Turkish EFL teachers experience a relatively low level of linguistic insecurity in general. Their major feeling of linguistic insecurity can be stem from their lack of confidence in their proficiency in target English which is English.

It is also revealed that Turkish EFL teachers perceive themselves quite efficacious during teaching process. Although 31 participants are not from the field of English language teaching, they feel quite confident about their classroom management, knowledge of English teaching strategies and their own capabilities.

The participants of the present study stated that they are satisfied with their Turkish accent and most of them believe that it is not very crucial to sound like native speakers of English in the classroom and they did not feel embarrassed to speak with a Turkish accent.

In the case of cultural issues, although the participants had positive attitudes towards the role of culture in foreign language teaching, they did not integrate culture-related classroom 
practices in their own classes frequently. This finding is consistent with the research finding of Atay et al. (2009). They believe that the two reasons that EFL teachers do not use cultural materials in the class might be lack of training or knowledge of integration of culture into foreign language education, and lack of opportunities to integrate cultural practices. In the other words, they might not have necessary resources such as computers, internet, DVD players, or tape-recorders.

\section{References}

Atay, D., Kurt, G., Camhbel, Z., Kas,hoglu, O., \& Ersin, P. (2009). The role of intercultural competence in foreign language teaching. Inonu University Journal of the Faculty of Education, Special Issue, 10(3), 123-135. Retrieved from http://www.acarindex.com/dosyalar/makale/acarindex-1423903323.pdf

Bandura, A. (1986). Social foundations of thought and action: a social cognitive theory. Englewood Cliffs, NJ: Prentice-Hall.

Bandura, A. (1997). Self-efficacy: the exercise of control. New York: Freeman.

Baron, D. E. (1976). Linguistic insecurity: The effect of attitudes toward language on language production. Flowers of Evil. Annual Meeting of the Modern Language Association.

Bucci, W., \& Baxter. M. (1984). Problems of Linguistic Insecurity in Multicultural Speech Contexts. Annals of the New York Academy of Sciences, 433, 185-200. http://doi.org/10.1111/j.1749-6632.1984.tb14767.x

Demirezen, M. (2007). Identity Problems of Non-native Teachers of English in Teacher Education. The Internet TESL Journal, 8(8). Retrieved from http://iteslj.org/Articles/Demirezen-NonNativeTeachers.html

Fraser, L. E. (2014). Teacher Efficacy Believes: How General Teachers Feel toward English Language Learners. Theses, Dissertations and Capstones. Paper 828.

Gagliardi, C., \& Maley, A. (2010). EIL, ELF, Global English: Teaching and Learning Issues. Linguistic Insights. Switzerland: Bern.

Garrido, C., \& Alvarez, I. (2006). Language teacher education for intercultural understanding. European Journal of Teacher Education, 29(2), 163-179. http://doi.org/10.1080/02619760600617342

Ghanizadeh, A., \& Moafian, F. (2011). The relationship between Iranian EFL teachers' sense of self-efficacy and their pedagogical success in language institutes. Asian EFL Journal, 13(2), 249-272. Retrieved from http://www.asian-efl-journal.com/PDF/June_2011.pdf

İnceçay, G., \& Akyel, A. S. (2014). Turkish EFL Teachers' Perception of English as a Lingua Franca. Turkish Online Journal of Qualitative Inquiry, 5(1). http://dx.doi.org/10.17569/tojqi.84118 


\section{Ml Macrothink}

Jenkins, J. (2004). ELF at the gate: the position of English as a Lingua Franca. IATEFL, Liverpool Conference Selections. Retrieved from http://www.hltmag.co.uk/mar05/idea.htm

Karakaş, A. (2012). Foreign Accent Problems of Non-native Teachers of English. Humanising Language Teaching, (5). Retrieved from http://www.hltmag.co.uk/oct12/mart06.htm

Labov, W. (2006). The Social Stratification of English in New York City (2nd ed.). Cambridge UK and New York: Cambridge University.

Labov, W. (1966). The Social Stratification of English in New York City. Washington, DC: Center for Applied Linguistics. http://web.stanford.edu/class/linguist62n/labov001.pdf

Maum, R. (2002). Nonnative English speaking teachers in the English teaching profession. Eric Digest, EDO FL 02-09. Retrieved from http://teachesl.pbworks.com/f/NNESTs\%2Bin\%2Bthe\%2BEnglish\%2Bteaching\%2Bprofessi on.pdf

Medgyes, P. (1992). Native or non-native: Who's worth more? ELT Journal, 46(4), 340-349, Oxford University. Retrieved from https://www.researchgate.net/publication/249252344_Native_or_non-native_Who's worth-more

Merç, A. (2015). Foreign Language Teaching Anxiety and Self-Efficacy Beliefs of Turkish Pre Service EFL Teachers. The International Journal of Research in Teacher Education, $\quad 6(3)$, 40-58. Retrieved from http://files.eric.ed.gov/fulltext/ED537806.pdf

Moreau, M. L. (1994), Nous avons la langue trop épaisseou comment être un francophone sénégalais, revue linguistique de Louvain. L'insécurité linguistique dans les communautés francophones périphériques, 20, 45-56.

Owens, Thomposon W., \& Paul M. Baker. (1984). Linguistic Insecurity in Winnipeg: Validation of a Canadian Index of Linguistic Insecurity. Language in Society, 13(03), 337-350.

Öztürk, G., \& Gürbüz, N. (2014). Speaking anxiety among Turkish EFL learners: The case at a state university. Journal of Language and Linguistic Studies, 10(1), 1-17. Retrieved from http://www.jlls.org/index.php/jlls/article/view/178/165

Sali, P. (2014). An Analysis of the Teachers' Use of L1 in Turkish EFL Classrooms. System, 42, 308-318. http://doi.org/10.1016/j.system.2013.12.021

Tschannen-Moran, M., \& Hoy, A. W. (2001). Teacher efficacy: capturing an elusive construct. Teaching and Teacher Education, 17(7), 783-805. Retrieved from http://mxtsch.people.wm.edu/Scholarship/TATE_TSECapturingAnElusiveConstruct.pdf 


\section{Copyright Disclaimer}

Copyright for this article is retained by the author(s), with first publication rights granted to the journal.

This is an open-access article distributed under the terms and conditions of the Creative Commons Attribution license (http://creativecommons.org/licenses/by/3.0/). 